\title{
Child Adoption Practices in the Bugis Community: Between Bugis Tradition and Ulama Views
}

\author{
Muhammad Yusuf* \& Ismail Suardi Wekke**
}

\begin{abstract}
Child Adoption Practices in the Bugis Community: Between Bugis Tradition and Ulama Views. This article reviews the tradition of adoption among Bugis people through the views of Bugis scholars and values of local wisdom. This research is a qualitative research using a content analysis approach. The study finds the fact that Bugis scholars have identified two forms of adoption practices. First, the practice of adoption as it is currently happening which change the nasab (lineage) so that it can inherit each other. Second, adoption practices that do not change the nasab. The first model is adoption that is prohibited in Islam in order to maintain the law and the descent according to the intentions of cultural values of paccing and sticking. The second model is allowed adoption. Such adoption practices are even encouraged if the motives are humanitarian motives and also in accordance with the values of the pesse culture (pacce), namely a deep sense of humanity and sibaliperri (mutual cooperation spirit).
\end{abstract}

Keywords: adoption, tradition, Bugis society, Islamic law, Bugis ulama

\begin{abstract}
Praktik Adopsi Anak di Masyarakat Bugis: Antara Pandangan Ulama dan Budaya. Artikel ini mengulas tradisi adopsi di kalangan masyarakat Bugis melalui pandangan ulama Bugis dan nilai-nilai kearifan lokal. Penelitian ini adalah penelitian kualitatif dengan menggunakan pendekatan analisis isi. Studi ini menemukan fakta bahwa ulama Bugis telah mengidentifikasi dua bentuk praktik adopsi. Pertama, praktik adopsi sebagaimana yang terjadi saat ini yang mengubah nasab sehingga dapat saling mewarisi. Kedua, praktik adopsi yang tidak mengubah nasab. Model pertama adalah adopsi yang dilarang dalam Islam demi menjaga hukum dan keturunan sesuai dengan niat nilai-nilai budaya paccing dan lempu'. Model kedua adalah adopsi yang diperbolehkan. Praktik adopsi semacam ini bahkan didorong jika motifnya adalah motif kemanusiaan dan juga sesuai dengan nilai-nilai budaya pesse (pacce) yakni rasa kemanusiaan yang mendalam dan sibaliperri (semangat gotong royong).
\end{abstract}

Kata Kunci: adopsi, tradisi, masyarakat Bugis, hukum Islam, ulama Bugis

\footnotetext{
*Sekolah Tinggi Agama Islam (STAI) Al-Furqan, Makassar, Indonesia

** Sekolah Tinggi Agama Islam Negeri Sorong

E-mail: m.yus56@yahoo.com \& iswekke@gmail.com
} 


\section{Introduction}

The ubiquitous adoption practice is not a new trend. Adoption of children (tabanniy) has a historical root that evolved before the advent of Islam, ${ }^{1}$ at the time of the Prophet Mohammad to the present. Therefore, the Koran, the religious text of Islam which Muslims believe to be a revelation from Allah, provides guidance on the limits that should and should not be in the practice. There are several factors that address the adoption of a child such as cultural factors in Java and Bali that are very different. However, Cultural factors in Sulawesi and West Nusa Tenggara are very similar in regards to the tradition of adoption, both do not change the status of an adopted child into a biological child, because Sulawesi and West Nusa Tenggara's religious belief is one where those inhabitants have strong Islamic roots. In contrast, the cultural factors of Bali and Java, which are very different, have some similarities that strongly influence their belief that they generally elevate and change the status of the adopted child into biological child. In Java, generally people separate a foster child from their own relatives with various motifs.

Later, the impact of globalization raises intensive acculturation that has brought about many victims and people who suffered tragic circumstances. Child birth without marriage is increasing over time due to degradation of spiritual, economic, social, and other factors. Thus, the unwanted babies are often found in the waste places or in a hospital abandoned by their parents. At the same time, couples who want children get a chance to make it happen in the form of adoption. The child status is improved by marking the adoptive father's name on their birth certificate.

${ }^{1}$ Muibi O. Opeloye, "Child Rights Act 2003 in Nigeria: What Implications for the Application of Child's Rights in Islam? "Proceedings Of Icwc 2016 Subang Jaya, Malaysia: p. 183. Amira al-Azhary Sonbol, "Adoption in Islamic Society: A Historical Survey." Children in the Muslim Middle East (1995): p. 45-67. Jamila, Bargach, Orphans of Islam: Family, Abandonment, and Secret Adoption in Morocco. Vol. 2. (Rowman \& Littlefield Publishers, 2002). Nawal El Saadawi, "Woman and Islam." In Women's Studies International Forum, vol. 5, no. 2, (Pergamon, 1982), p. 193-206. Avner Gil'adi, Children of Islam: Concepts of Childhood in Medieval Muslim Society. (Springer, 1992). 
The clash between the facts of socio-cultural community with the ideals of Islamic law have also begun to emerge. ${ }^{2}$ Adoption which was originally considered as a solution to overcome the families to have children leads to conflict. It was triggered by inheritance issues, guardianship, and psychological impact. Cultural communities are sometimes not in line with the standards of Islamic law. Islam does not allow the adoption of children which results in changing nasab status, whereas the culture commonly addresses the adoption practices in the ignorant society. Explanations and intensive socialization are needed to understand the Bugis community in three positions; 1) as citizens who must comply with the applicable regulations, 2) as Muslims who should be subject to the laws of Islam, and 3) as Bugis people who have much local wisdom.

\section{Understanding Adoption, Motif, and related Issues Understanding Adoption}

Adoption has two definitions. First, taking other people's children to be raised and educated with great care and affection, and those children are treated by adoptive parents as their own children. Second, taking other people's children to be given status as biological children, so they are entitled to use nasab of the foster parents and inherit their legacy, and other rights in respect of a child relationship with parents. ${ }^{3}$

The first definition refers to Al-Qur'an and Sunnah of the Prophet after the revelation of verses telling the Prophet not to give a child biological status to Zaid bin Haritha, a slave or war prisoner freed by the Prophet and adopted as his biological son. Meanwhile, the latter is the form of adoption practice in the pre-Islamic Arab society. The

2 Talbani Aziz, "Pedagogy, Power, and Discourse: Transformation of Islamic Education." Comparative Education Review 40.1 (1996): p. 66-82. See also Rasid, Yunus, "Transformasi Nilai-nilai Budaya Lokal Sebagai Upaya Pembangunan Karakter Bangsa." Jurnal Penelitian Pendidikan 13, no. 1, (2016).

${ }^{3}$ Mahmud Syaltut, Al-Fatawa (Mesir: Dar al-Qalam, t.t.). See also Masjfuk Zuhdi, Masail Fiqhiyah (Jakarta: CV. Masagung, 1994), p. 28. See also Khoiruddin Nasution, "Perlindungan Terhadap Anak dalam Hukum Keluarga Islam di Indonesia”, Al- Adalah 13, no. 1 (June 2015): p. $1-10$. 
second definition has been entrenched in some community, including Indonesia. In Bali ${ }^{4}$ for example, child adoption is witnessed by religious leaders and then the child officially becomes a full member of the family who raises them, and they share their inheritance rights. This is in contrast to the tradition of the people in South Sulawesi, especially the Bugis community. In general, the adopted child is related to both the biological parents and his adopted family after his adoption, but he is not entitled to be heir of the adoptive parents and the family, but he could obtain inheritance with grant status. ${ }^{5}$ This works well due to strong influence of Islam in South Sulawesi. However, it is shifted along with the development and acculturation. So in some cases the understanding deviated from Islamic teachings that are also found among Bugis community. Apart from the influence of other cultures, it also occurs as a form of negligence Muslim leaders, Islamic organizations and preachers who do not make the adoption of children as a theme in his lecture.

\section{Adoption Motives}

Fostering or adoption of children occurs because of several motives. ${ }^{6}$ The motive of adoption can be seen on the part of the adoptive parents and the biological parents. These motives can be identified as follows on the part of the adoptive parents: (1) they want to have children or heirs; (2) they want to have a friend for them or for their children to address needs of loneliness (3) they want to create a sense of social compassion towards others; (4) they seek the chances of adoption which are allowed by regulation; and (5) they desire the presence of certain people who advocate the adoption of a child. ${ }^{7}$

\footnotetext{
${ }^{4}$ Masjfuk Zuhdi, Masail Fighiyah, p. 28.
}

5 B Ter Hear Bzn, Beginselen en Stelsel van het Adat Rech, trans. Soebakti Poesponoto, (Jakarta: Paramadina, 1976), p. 182-184. See also Masjfuk Zuhdi, Masail Fiqhiyah, p. 28.

${ }^{6}$ Richard M. Ryan, and Edward L. Deci. "Intrinsic and Extrinsic Motivations: Classic Definitions and New Directions." Contemporary Educational Psychology 25, no.1, (2000): p. 54-67.

7 See Khusdjono. "Pengangkatan Anak dan Akibat Hukumnya Terhadap Harta Benda Perkawinan Orang Tua Angkat (Studi Pada Masyarakat Tionghoa di Kecamatan Senapelan Kota Pekanbaru)." Premise Law Journal 2, (2015). Filemon Sangian, "Hak Atas Warisan Seorang Anak yang Diadopsi Terhadap Orang Tua Walinya Menurut KUH Perdata." Lex 
The Bugis community tradition has a varied culture related to adoption. First, because of their culture or paccepesse '(compassion, solidarity, humanism). Pesse is a character belief that elicits a strong sense of profound humanism. Second, adoption is usually performed because one is financially secure or has the material wealth to support the individual.

Third, Some people select to be a foster or adoptiveparent to get free child labor opportunities (pakkareso), helping them in their activitiesthey are involved in. This motive is stronger among farmers, planters and businessmen. In the past, models such as childbirth for atta (slave), has now changed to workers (pakkareso) only. Fourth, another motive is a means to have children easily according to the beliefs of Java. This is called an inducement child. This motive is employed by people who are already relatively old, or married and normally must have their own offspring, but they cannot do so. Adoption in this motif of trust consists of only a small proportion that occurs in Bugis society where they provide the adoptive parent's family name to the adopted child (penisbatan).

The motive of putting one's children up for adoption by the biological parents can usually be identified as follows: First, they feel unable to raise enough money to support their children. This motif occurs more frequently in communities (biological parents) who are economically weak; second, the culture practice of adoption is highly accepted and at the same time there are those who are willing to adopt the child; third, the rewards that biological parents will receive from the prospective adoptive parents because of the adoption of their children; fourth, the biological parents want their son to have a brighter future which he may be able to get from a more responsible person with more financial sustainance (material); fifth, the biological parents have enough children so they are more willing to hand over some of them to the other parties willing to adopt them; sixth, the mother does not have the ability both

Et Societatis 5, No. 2 (2017). Rany Puspita, "Adopsi Anak (Studi Deskriptif Tentang Latar Belakang dan Nilai Anak Bagi Pasangan Suami Istri Yang Mengadopsi Anak).” Phd Diss., Universitas Airlangga, 2006. 
mentally and financially to educate and care for her child or children; seventh, few or no community members understand the status of Islamic law on the appointment (adoption) of the children; seventh, because biological parents do not want to bear the shame of having children born out of wedlock who are only legitimate as results of adultery; and eighth, biological parents want only for their child to inherit from the adoptive parents. ${ }^{8}$

In the Bugis community most of the adopted children are results of biological parents who not understand the Islamic law on the legal status of adoption, followed by those children born out of wedlock, and then the inability of financial stability. A husband and wife from among the civil servants who are university lecturershave two adopted children and do not have any biological children. Both of these adopted children bore his family name which shows that he changed their status to his biological children. The hope is that both adoptive children have a legitimate inheritance rights under applicable laws and regulations. ${ }^{?}$

${ }^{8}$ Among the motives that are identified There also are adopting his own because he had no biological children and some who do not have a spouse. This occurs in some women who do not have children. Indeed, some have married the adopted child with a woman from his own family generally married with children his own brother. Thus, the adopted child comes from his own nephew and niece. Once married, he lived with his foster parents and will inherit all future wealth legacy. It is certainly to be seen from two sides. As their adopted children are not entitled to inheritance, but as a nephew / niece they were entitled to inherit his wealth in accordance formulations in faraidh. See Ria Ramdhani, "Pengaturan Wasiat Wajibah Terhadap Anak Angkat Menurut Hukum Islam.” Lex Et Societatis 3, no. 1 (2015). Tresna, Hariadi, "Hak Anak Angkat dari Orang Tua Angkat dalam Hukum Islam (Studi Pada Pengadilan Agama Medan).” Master's thesis, 2004. S. Zilal and M. Y. Farahwahida. "Penyusuan Anak Angkat: Satu Analisis." Prosiding Persidangan Antarabangsa Kekeluargaan dari Perspektif Global. Johor Bahru: KPIJ PRESS (2014): p. 124-144. Ahmad Syafi'i, "Adopsi dalam Perspektif Hukum Perdata, Hukum Adat dan Hukum Islam." HUNAFA: Jurnal Studia Islamika 4.1 (2007): p. 49-62. Jatmiko Winarno, "Akibat Hukum Pengangkatan Anak." Jurnal Humaniora 1, no. 2 (2013): p. 1-14. Haedah Faradz, "Pengangkatan Anak Menurut Hukum Islam.” Jurnal Dinamika Hukum 9, no. 2 (2009): p. 191-198. Enik Isnaini, "Hukum Hibah Wasiat Terhadap Anak Angkat Menurut Hukum Perdata." Jurnal Ilmu Sosial dan Humaniora. Fakultas Hukum Universitas Islam Lamongan.

${ }^{9}$ The biggest mistake of this is because as a Muslim scientists do when they should conduct a study on the status of adopted children in Islam, inheritance rights, custody. In addition, as a scientist it will provide a strong influence in the community because the community to make it as reference to the notion that similar practices it is true because it is done by scientists. 
In this study, only Bugis parents were evident for all the adopted children and only one of those adopted children was identified as the adopted son of biological parents of Bugis descent. Most of the foster childrenwere taken from the hospital and they were found in certain places that allegedly are known for biological parents abandoning their children leaving no traceability. In contrast, to the adoption without changing legally their nasab, these adoptive parents generally take a child as a foster child of their family. Culture of pesse (humanist sense) still characterizes the patterns of adoption partly because there is also the adoptive parents who do not understand the Islamic law on adoption of the child, that it should incorporate the provision a future inheritance.

The occurrence of promiscuity causing aberrant behavior (adultery) in major cities such as Makassar, or because of the negative influence of the media that has resulted in many children born out of wedlock that are illegitimate children. As a result, the child has the unfortunate fate of ending up in a trash bin or elsewhere after birth with no mother. It happens because the biological parents are not ready to be responsible and bear the shame (siri). ${ }^{10}$ This is also possibly motivated by the cost of the wedding (bride and two Balanca or pappanai) not covered by offenders, especially the biological father, because the cost of marriage is considered expensive and he does not have sufficient income to support a family, especiallya child born out of adultery.

In addition, in several hospitals in the city of Makassar there are many abandoned children whose biological parents were unable to pay the cost of labor, bear the shame, or accept the child and for other reasons. Hence, the biological parents may leave the child abandoned in a hospital. If the child is abandoned at a hospital, they hope that there are people who may come to the hospital in search of abandoned children. It is common that couples from families who have no heirs are also looking for these conditions to have children, so they negotiate with the hospital to pay the cost of labor and the cost of the administrative

${ }^{10}$ Siri in Makassar culture that once regarded as self-esteem, self-worth, now shifted to the negative stigma. As a result, it has been eroding and relieve pacce (Makassar) or pesse (Bugis), the sense of humanity high. 
management of the hospital. ${ }^{11}$ Furthermore, in these cases, they submit to government agencies authorization to provide legalitasi status of the child in the family of the adoptive parents with all the rights and obligations attached to it.

\section{Several Issues Regarding Adoption}

Family problems involving parents who do not have offspring usually do polygamy (polygyny) as a solution if the problem is with the wife. In addition, an alternate solution is adopting a child. As previously mentioned, the adoption of these children has been a long-standing problem since thedays of ignorance before the teachings of the prophet Muhammad came into effect. The difference between the practice of ignorance before and after Muhammad became a prophet are very clear. The practice of adoption after Muhammad was assigned as a prophet is taking another person's children cared for and educated, and treated by adoptive parents as his or her own without giving birth to the child. ${ }^{12}$ While at the time of the adoption when ignorance became understood as the act of taking other people's children to be given status as biological children, so the child is entitled to use nasab of their foster parents and inherit the parents' legacy,

The second model was decided by the religion of Islam, ie removal of the legal status of adoption as a practice that does not change the

${ }^{11}$ Some of the children of adoption results have known that he was adopted from foster parents, but they do not know anymore where biological parents again. Information about the status of the adopted children came from a friend who knew the family's adoptive parents. There is also a small portion of the DNA test to know (blood). Since it was educated so he put the question to his adoptive parents. At that moment there was no other way except to be given an honest answer that he was a foster child. However, the problem does not stop there, it appears the psychological impact on the child.

${ }^{12}$ Amira al-Azhary Sonbol, "Adoption in Islamic Society: A Historical Survey." Children in the Muslim Middle East (1995): p. 45-67. Nilüfer Göle, "The Voluntary Adoption of Islamic Stigma Symbols." Social Research: An International Quarterly 70, no. 3 (2003): p. 809-828. RajabiArdeshiri Massoud. "The Rights of the Child in the Islamic Context: The Challenges of the Local and the Global." Int'l J. Child. Rts. 17 (2009): p. 475. Shabnam Ishaque, "Islamic Principles on Adoption: Examining the Impact of Illegitimacy and Inheritance Related Concerns in Context of A Child's Right to An identity." International Journal of Law, Policy and the Family 22, no. 3 (2008): p. 393-420. M. Fakhr El-Islam, "Arab Culture and Mental Health Care." Transcultural Psychiatry 45, no. 4 (2008): p. 671-682. 
status of the child nasab with all the accompanying legal implications. Appointment of children being taught the Qur'an is not to change the status of the child and also does not alter the rights and obligations of the biological parents and their families.

The problems that arise in the community are due to their ignorance about the religion of Islam. As a result, the current practice is still found in some cases as similar to the period of ignorance. It is certainly a challenge that emerged as a result of acculturation, globalization, and the negligence of the elite Muslim communities both at a structural level (executive and legislative) and cultural level (preacher, priest, anregututta 'and Islamic organizations). In this case the scholars and umara 'should enlighten people and and the state must provide regulation in accordance with Islamic teachings and the character of local wisdom which is relevant to the teachings of Islam which applies to Muslims.

The Qur'an gives an example of a very firm when giving instructions and ultimatums to the Prophet so that he does not give status to his adopted son, Zaid ibn Haritha (son of Haritsha) which was originally the Prophet gave the name of Zaid bin Muhammad (Muhammad's son Zaid). Prior to the ban through Quranic revelation heare is not called "Zaid" based on his father's name (Haritsah) but replaced with a name called Zaid bin Muhammad. Prophet Muhammad Saw announced to the Quraysh and said: "bear witness that Zaid, I will make my foster child, he is my descendant and I will inherit him or her." The attitude of the Prophet Muhammad. It is a reflection of the tradition that existed at that time. Hence the Prophet regarded as his son, then the friend also called him or her the "Zaid ibn Muhammad".

Making a nasab between a genealogical adopted child and the adoptive parents is a unlawful. It causes people to confuse the meaning of nasab, change the rights of inheritance that causes a legacy to the unauthorized and eliminate inheritance rights to those who are entitled, justify the unlawful, namely seclusion (gathering with mahram), and forbid lawful, namely marriage. This is actually anticipation that maintains nasab law.

Prophet says: "Anyone who accuses him as the son of a not her 
father, then her overwritten anathema of the angels and mankind. And later on the Day of Judgment, will not be accepted regular practice, either mandatory or that sunnat. "(H.r. Bukhari).

While the determination of adoptions under Islamic law in the Religious Court, under Article 171 letter (h) Compilation of Islamic Law in force in Indonesia, Presidential Decree No. 1 of 1991 dated June 10, 1991 stipulates that the cost of living and education of the adopted child is shifted to the responsibility of the adoptive parents from the original parents by a court decision.

According to Islamic law adopted children are not entitled to inherit from their adoptive parents and maintain nasab between the adopted child and their biological parents. ${ }^{13}$ The financial relationship between the adopted child and the parents who raise them is recommended in the form of a will or a grant, the maximum amount of $1 / 3$ (one third) of the parent's property, and the will is required. In Islamic law, there is no limit on the age, both in terms of the adopted child or of the adoptive parents and no rules as to whether the prospective adoptive parent status is married or not (single parent adoption), adoption by the prospective adoptive parent status mating, and the removal of children by a widow or widower (posthumously adoption). These include the removal of adult children ('aqil baligh) especially when they get married, as long as there is no prohibition in Islamic law. Islam mandates that the adopted child with the adoptive parents must be the same religion, namely Islam. This is based on the intent of law, namely maintaining religion and aqîdah.

\section{Children Adoption in the Qur'an and the views of Bugis Islamic Scholars to Adoption}

After Muhammad Saw. becomes Rasul, surah al-Ahzab verse 4, paragraph 5 comes Paragraph 37 and Paragraph 40 which basically prohibits adoptions by calling legal consequences as a "natural child" and

${ }^{13}$ Munadi Usman, "Adopted Children and The Right of Civilization According to the Qur'an.” QURANICA-International Journal of Quranic Research 10, no.1, (2018): p. 27-40. 
they inherit each other as did the Prophet Muhammad. Scholars agree that the verses respect the events of Zaid bin Haritsha. Through these events can be understood as suggesting that the removal of the children was permissible because the Prophet Muhammad had been practicing them. However, adoption does not change the status of a person nasab, because Allah Swt has revealed in the Qur'an that Zaid nasab status should not be attributed to the Prophet Muhammad.

a. Q.s. al-Ahzab [33]: 4

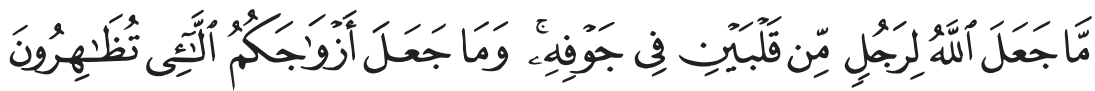

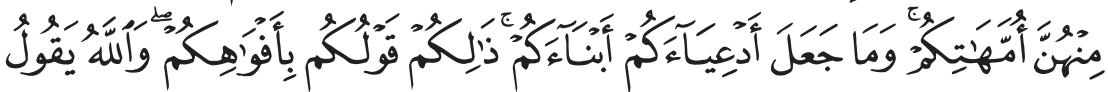

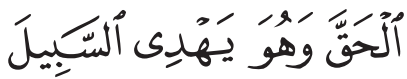

God does not make someone two hearts in their sockets; and He does not make your wives you zhihar as your mother, and He does not make your adopted children your biological children (themselves). That is just your word in your mouth. and God tells the truth and He shows the way (right).

b. Q.s. al-Ahzab [33]: 5

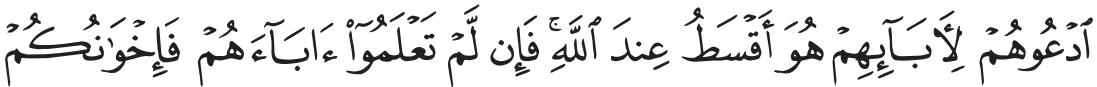
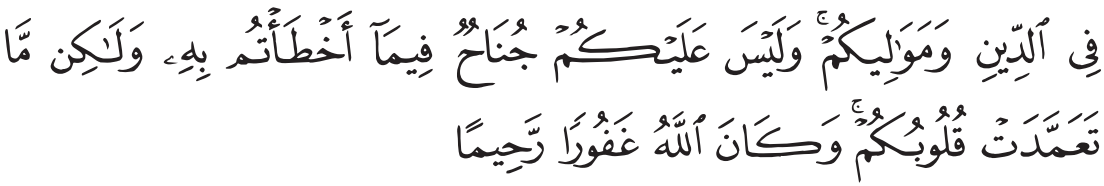

Call them (adopted children) with (using) the names of their fathers; That is more just to the sight of God, and if you do not know their fathers, then (call them) your brothers and sisters, your ancestors, and there is no sin on you against what you err on it, but what you have intentionally has. and Allah is Forgiving, Most Merciful.

c. Q.s. al-Ahzab [33]: 37

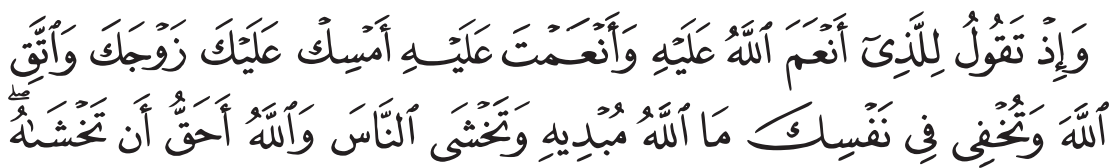




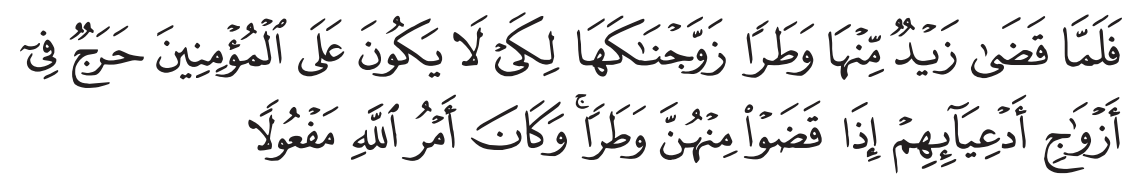
and (remember), when you say to the person whom Allah has bestowed favor on him and you (also) have blessed him: "Hold your wife and fear Allah", while you hide in your heart what Allah will reveal, and you fear of humans, while Allah is the one who has the right to fear. So when Zaid ended the need for his wife (divorced him), We married you with him so that there was no objection for the believers to (marry) the wives of their adopted children, if the adopted children had completed their needs rather than his wife and it is Godis decree that is sure to happen.

Islam law forbids the practice of adoption with a legal effect as adoption in the future of ignorance, the removal of children who changed the status of an adopted child into biological children of adoptive parentssevering ties with their biological parents. Hence, adopted children became heir to the adoptive parents who become their absolute guardians. Islam recognizes only the adoption of children in terms of shifting the responsibility for providing a living, education, nurturing environment, and other areas in the context of worship to Allah Swt. based on humanitarian grounds.

Maintenance and sponsorship for the poor, displaced and orphaned children is the responsibility of the state according to Article 34 of the 1945 Constitution. As citizens, the people of Indonesia can take a role in realizing the objectives of the country in line with the surah al-Dahr paragraph 8:

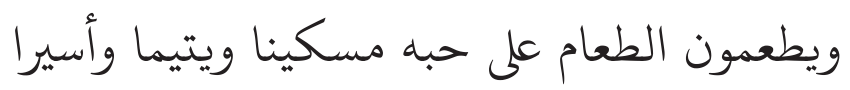

"And they give food that he liked to the poor, the orphan and the captive".

Based on the verses above, adoption of children is based solely on the basis of humanity, and seeking the pleasure of Allah, and not to inherit each other's affairs. As quoted by the Indonesian Muslim Scholars Council (MUI) as a cornerstone of his fatwa about tabanny (adoption), 
expressed as follows: "In Islamic law, tabanny classified into two forms, one of which is that a pick up other people's children to be treated like a child of their own, in order to give affection, a living educational and other purposes, and the child is legally not his". ${ }^{14}$

At the time of ignorance, someone receives a boy as his son with such privileges as a biological child. Invoked in the name of his adoptive father and inheritance, Islam forbids tabanny (adoption) where children are recognized as biological children, and Islam aborts all the usual rights of the adopted child obtained mutabanniy (people who adopt a child) as the word of Allah in Q.s. al-Ahzab [33]: 4.

Someone is forbidden to his nasab on his adopted son. The nasab must be refered to his original nasab of the biological child, if known. If not, call them akhfi al-dîn (coreligionists) or Maula (someone who has made an adopted child). As Salim, the adopted son Hudhayfah, called "Maula Abi Hudhayfah" as the word Allah on Q.s. al-Ahzab [33]: 5 it.

Islam also prohibits tawaruts (inheritance with each other) between the child and the adoptive father. When Allah, abrogated the law (legality) the adopted son, Allah was allowed to marry his adopted son's wife or vice versa. Allah's Apostle had married with Zaynab bint Jahsh al-Asadiyyah, the former wife of Zaid bin Haritsha. The goal that does not exist for a believer to marry ex-wives of their adopted sons. When the adopted sons have completed their iddah, from his wife (after divorce and expiration 'iddahnya), then they may marry them.

\section{The Bugis Muslim Scholars Views}

The Bugis scholars, in this article, refer to the writer team of tafsîr of South Sulawesi, ${ }^{15}$ namely AG. H. Abd. Muin Joseph (1920-2004),

${ }^{14}$ See Euis Nurlaelawati, "Menuju Kesetaraan dalam Aturan Kewarisan Islam Indonesia: Kedudukan Anak Perempuan versus Saudara Kandung." Jurnal Indo-Islamika 2, no. 1 (2012): p. $75-9$.

${ }^{15}$ In South Sulawesi there are several works of Bugis language interpretation of the Koran. Bugis language commentary referred to in this article is a commentary written by scholars who pioneered by MUI Bugis of South Sulawesi. This commentary contains 30 chapters interpretation of the Koran and titled in ArabicTafsir al-Qur'an al-Karim and titles in Bugis "Akorang Tafesere Mabbasa Ogi" MUI Sulsel prepared by a team headed by AG. 
AG. H. Makmur Ali (1925-200 AD), AG. H. Hamzah Manguluang (1925-1998 AD), AG. Djunaid Muhammad Sulaiman H. (1921 AD / 1339 AH-1996 AD / 1417 AH), GH Andi Syamsul Bahri (b. 1955 CE), MA, AG. Mukhtar H. Badawi (d. 1992), and some scholars who do not have his name included in the Preamble of the interpretation of the first volume. Other scholars who are not recorded AG. H. Muhammad Farid Wajdi, MA., AG.H. Abdul Wahab Zakariyah, MA., and others. ${ }^{16}$

Quranic verses about the adoption of children described above, the Bugis scholars interprets this more reliant upon referral nothing compared to seeing the local culture and norms. In the 1980s when the commentary was written, beneficiaries are still considered to be sufficient consideration to take the opinion that has been prevalent in the books of tafsir. However, this time is completely changing circumstances, so that the rhythm of the law must be able to be adjusted to developments that are applicable to a variety of challenges.

Q.s. interpretation, al-Ahzab still considered paragraphs 4, 5, 37 which are still relevant to local culture at that time. Today, it is experiencing challenges that require excellent idea. Globalization with all the effects thereof, the Muslims as drifting. The practice of adoption in some cases occurs with the understanding of adopted children which lead to changes in family status. As explained on Q.s. al-Ahzab [33]: 4-5 team Bugis scholars say that this verse comes as a warning to the prophet Muhammad on adoption done by Zaid son of Haritsha. AlTabanniy is a long tradition of Arab society to the decline in the verse. The Prophet did so before the revelation of this verse, as well as some friends. The following was stated in his commentary:

H. Abd. Muin Yusuf in his capacity as Chairman of the MUI South Sulawesi. Initially, the interpretation book consists of 10 volumes, then reprinted and reproduced by MUI South Sulawesi. In the subsequent mold changes in the number of its volumes to 11 volumes. At first, 10 volumes it contains three chapters, but because of the volume 10 is considered too thick, so it is divided into two volumes. H. Syamsul Bahri Andi Andi Galigo, Interview, Malaysia Negeri Sembilan, 2008. See also MUI South Sulawesi, 1988, Tafesere Akorang Mabbasa Ogi, Volume 1 (Ujung Pandang: MUI Sulawesi, 1988), p. vii.

${ }^{16}$ MUI South Sulawesi, Tafesere Akorang Mabbasa Ogi, Volume 1, p. ix. Syamsul Bahri Andi Andi Galigo, Interview, Malaysia August 28, 2008. 


\section{Lontarak Script:}

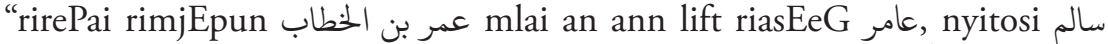
rialai an adoptive ri حذيفة, المقدار rialai an ri الأسود بن عبد يغوث, aEREeG زيد rialai an adoptive rinbit

Transliteration:

"Rirampei rimajeppu'na Umar ibn al-Khattab panicles ana 'ana'na lift riasengnge 'Amir. Salim Naiyyatosi rialai ana 'lift ri Huzaifah, naiyya Miqdar rialai ana' ri 'Abd al-Aswad Yaguts. Zaid Enrengnge rialai ana lift ri Nabitta’ Saw. “

\section{This means:}

-in history- mentioned that Umar took a foster child, the child named Amir. While Salim is taken as a foster child by Huzaifah. As for al-Miqdar taken as a foster child by al-Aswad ibn Abd Yaguts. While Zaid taken as a foster child by the Prophet.

It can be concluded that Zaid was a slave freed by the Prophet. based on the hadith narrated by Bukhari and Muslim, al-Tirmidziy, and al-Nasai from Ibn Umar. Because he was freed by the Prophet, then he was appointed as a child with the attribute name to Zaid bin Muhammad (Muhammad's son Zaid). In connection with this, verse 4 of the Surah al-Ahzab is coming. Then the Prophet reinforces thenceforth that Zaid no longer attributed his name to Muhammad but Zaid ibn Haritha ibn Sarahil. ${ }^{18}$

The explanation is more emphasis on the events of the Prophet, and Zaid compared between friends with adoptive children. ${ }^{19}$ This is reasonable, because a point of emphasis in this Bugis scholars like to clarify that the Prophet Saw. Any prohibited Zaid name attribute to the name of the Prophet but must be attributed to the Prophet returned

${ }^{17}$ MUI South Sulawesi, Tafesere Akorang Mabbasa Ogi, Volume 8, p. 484.

${ }^{18}$ MUI South Sulawesi, Tafesere Akorang Mabbasa Ogi, Jilid 1, p. ix. H. Andi Syamsul Bahri Andi Galigo, Malaysia Negeri Sembilan, Interview, MUI team Sulsel, Tafesere Akorang Mabbasa Ogi, Jilid 8, p. 284-285.

19 Van IJzendoorn, Marinus H., and Femmie Juffer. "The Emanuel Miller Memorial Lecture 2006: Adoption As Intervention. Meta-Analytic Evidence for Massive Catch-up and Plasticity in Physical, Socio-Emotional, and Cognitive Development." Journal of Child Psychology and Psychiatry 47, no. 12, (2006): p. 1228-1245. 
his biological father. It is a great lesson that with the decrease in the verse, Muslims are no longer allowed to practice adoption which has implications for the legal problems inherited each other. Therefore, adoption (adoption) was announced by the Prophet. That Zaid is not only liberated but also it has implications for the inherits. It is described in the book of Bugis language commentary:

Lontarak script:

"Men sbini rimjEpun زيد aupmredkni. toni aual an nmnk aumntoai. agn msEnn epnEdin shredded زيد زaREeG amauern riaEtu pd naitn alEbirEn

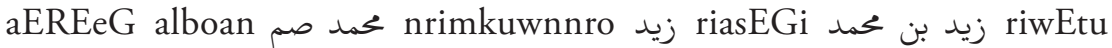

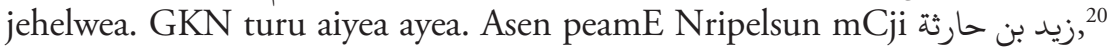

Transliteration:

"Zaid rimajeppuna mennang Sabbini upamaradekani. Toni Uala ana 'namanaka' upamanatoi. Agana masennangna feneddingna ambo'na Zaid enrengnge amaorena riwettu fada naitanna alebbirenna enrengnge alaboanna Muhammad. Narimakkuannanaro riasengngi Zaid Zaid ibn Muhammad riwettu Jaheleae. Gangkanna down aya’e iyyaewe. Napalesuni paemeng asengna mancaji Zaid ibn Haritha."

This means:

"Please tune in to you, that I freed Zaid now. I also picked it as a child, I have the right to inherit and he was entitled to inherit me. By doing so, his father (Haritsah) and uncle were delighted when they saw the glory and the kindness of the Prophet Muhammad heart. That is why, Zaid called Zaid ibn Muhammad when the times of ignorance. Finally this verse came. Then, restored to its name to Zaid ibn Haritha."

MUI team consisting of Bugis Muslims Scholars explains that the events of the decline in the verse clearly shows that the adopted child and the adoptive parents may not inherit each other (tawaruts) and must be returned to the attribute name with her biological father. The practice of adoption in Islam should not lead to breakup nasab ${ }^{21}$ and

${ }^{20}$ MUI South Sulawesi, Tafesere Akorang Mabbasa Ogi, Volume 8, p. 488-489.

${ }^{21}$ Ibn Kathir when explaining the purpose of Q.S. al-Nisa [4]: 23 that is expressly forbidden for Muslims former wives biological child. It aims to eliminate the false assumption regarding bolehnya not marry the former wife of the adopted children as they occur in the pre-Islamic era (ignorance). 
the implications of inheritance law. It can only be tolerated if there is no change of nasab.

The mention of the name of the adoptive parents in the name of the adopted child could simply use the word "Maula" for example Salim called "Maula Hudhayfah" which means that Salim is a foster child Hudzifah but did not use the word "ibn/bin" in the name. ${ }^{22}$ This was explained when they explain the meaning of Surah al-Ahzab verse 5. It can also be seen when they decompose Q.s. al-Ahzab [33]: 37. When they interpret the verse, explanations are grouped verses 37-40. Against the Paragraph group, they provide special topics "kisn زينب بنت جحش sibw (23 It shows that the historical event about domestic violence bintu Jahsh Zainab and Zaid bin Haritha experiencing disharmony. This is evident they explain in particular paragraph 37.

... So when Zaid had put an end to the purposes of his wife (divorced her), We marries you with him so there was no objection to the Believers to (marry) the wives of their adopted sons, when the adopted children had been dissolved with the necessary than his wife ...

According to the Bugis language interpreter teams that Zaid divorced his wife (Zainab) then Allah commanded the Prophet to marry Zainab. In fact, God himself who married the Prophet with Zeinab, the former wife of his adopted son.

Script Lontarak

"riwEtu purnn npllo aktn زيد NSB ribaienn ntElEn. ripsialni nbit صم sibw kuwmEGi ajgg apoetan know mtEpEea pobaienai baienn poro an adoptive $\mathrm{n}$ nerko Purni npurai baienn koritu." ${ }^{24}$

Transliteration:

“Zaid akkatana puranana Riwettu napalalo ribainena nasaba natelle'na. Ripasialani Nabitta 'Saw. Zainab sibawa kuwammengngi aja'gaga appoteanna tau ana bainena mateppe'e pobainei poro 'lift na narekko Purani napurai bainena koritu".

\footnotetext{
${ }^{22}$ MUI South Sulawesi, Tafesere Akorang Mabbasa Ogi, Volume 8, p. 490-491.

${ }^{23}$ MUI South Sulawesi, p. 586.

${ }^{24}$ MUI South Sulawesi, p. 596.
} 


\section{This means:}

When Zaid has completed intention to his wife to divorce him, then the Prophet married to Zainab so no no believer who refused - for reasons the former wife of his adopted son - so do not want to marry someone who hasbeen officially divorced

Verse 37 explains that the adoptive parents and the adopted child does not change the status of mahram, namely that the two can get married. Verse can lift women marry his adopted son, and the foster mother to marry his adopted son males along not because of other factors such as one mother, or mahram status is already occurred before it became a foster child status. Whatever the reason, adoption remains the mahram status which will not change, because it is already firmly in Islam through the verses of the Qur'an and various history. If the attribution name adopted child to the adoptive parents has occurred it must be dismissed and ask forgiveness to God. ${ }^{25}$ The violations occurred with the adopted child the name attribute to the name of his adoptive parents because of ignorance of God with the terms submitted to dismiss all legal impacts that have occurred as inherited, attribute names, and others should be returned to their home as before the adoption occurred.

\section{Bugis Cultural Perspectives on Adoption}

Local wisdom values adopted (approved) in the Bugis community culture now are some not in line with the behavior of the community. As known that the adoption of children is a cultural phenomenon that has historical roots since pre-Islamic exists. Bugis society is really a community or tribe that has diverse social strata. Bugis social strata in society were seen from the origin of descent. In general tradition of adoption does not change the legal status of a foster child, a good relationship with mahram or relation to guardianship and inheritance, although some cases already exist of which are not aligned in perspective of pangadereng consisting of law, religion, and culture. ${ }^{26}$

${ }^{25}$ Abu Abdullah Muhammad al-Qurthubi, Jami' li Ahkam al-Qur'an, 14 Juz (Mecca: Muassasah al-Risalah, t.t.), p. 109.

${ }^{26}$ Muhammad Aras Prabowo, and Hadri Mulya. "Construction of Ethic Code of Public 
There are several local moral values associated with the culture of the Bugis community in the practice of adoption.

1. Sibaliperri 'Bugis usually encourages people to do the practice of adoption in order to help the families or others in need, both the biological parents who have financial limitations ${ }^{27}$ nor the adoptive parents who require the presence of the child, especially when they are old already. ${ }^{28}$ This is in accordance with God's word is a command for mutual help in goodness and piety and do not help in sin and enmity ${ }^{29}$ (conflict). Relief sincere contains no motive to manipulate for personal gain without accommodating the interests of other parties.

2. Siri '(shame) which is the main principle of the Bugis community. Siri 'originally has meaning which connotes positive, but can also be a negative connotation. ${ }^{30}$ Siri is often interpreted as a value or dignity. Therefore, if someone is doing things that are not good, it's a shame (mappakasisri'). Mahram in Bugis culture referred to masirina, ${ }^{31}$ that is, those responsible for maintaining and protecting the self-esteem. Based on the culture of siri", an adopted child who is female, when entering adulthood (adolescence) it should not be left alone with his stepfather because based on Pangadereng especially Sara' (Shari'a) between the adoptive father

Accountant in Perspective of Value of Bugis Culture." International Journal of Applied Business and International Management 3, no. 2, (2018): p. 5-18.

${ }^{27}$ This is in accordance with the 1945 Constitution, article 34 and Surah al-Dahr verse 8 .

${ }^{28}$ Adoption practice with this kind motif found in several kabupaten in South Sulawesi, and is usually done by the adoptive parents who do not have biological children. Generally, taken from a nephew or niece of sudaranya own child. However, still need to be explained to the public because it turns out though does not change the status kemahraman but its provision is usually on inheritance property, not a grant or a will. As a nephew or niece is entitled to inherit in accordance with the law, but as an adopted child is not entitled to inheritance.

${ }^{29}$ Q.s. al-Maidah [5]: 2.

${ }^{30}$ A. Rahman Rahim, Core Values Culture Bugis (Yogyakarta: Waves, 2011), p. 139-140. Ismail Suardi Wekke, "Islam dan Adat: Tinjauan Akulturasi Budaya dan Agama dalam Masyarakat Bugis." Analisis: Jurnal Studi Keislaman 13, no.1, (2017): p. 27-56; "Islam dan Adat dalam Pernikahan Masyarakat Bugis di Papua Barat." THAQAFIYYAT: Jurnal Bahasa, Peradaban dan Informasi Islam 13, no. 2. (2014).

${ }^{31}$ Rahman Nurhayati, Voices in the Locality (Makassar: Lagaligo Press, 2012), p. 130. 
and the adopted son daughter is not a mahram as between the adopted male child and adoptive mother.

3. Pesse (Ibah, affectionate, humanitarian, solidarity). ${ }^{32}$ Pesse value is a sense of compassion and humanity that grows in the hearts of people to help others, especially guarding the children's future, good faith and education. This is one form of implementation of honesty (alempureng). In the context of Bugis culture, it is said: "EPPA 'gau'na lempu'e: risalaie naddampeng, riparennuangie temmacekko bettuanna risanresi teppabbelleang, temmangoangenngi tenia alona, tennaseng Deceng Rekko dénassamari pudeceng", There are four core honest acts: forgive the mistakes of others to him, to be honest in accepting the mandate which means there is a traitor, not greedy and does not take that is not right, he did not consider the goodness except good for others. One aspect that honesty is the principle that kindness should feel kindness for others (tennaseng Deceng Rekko denassamari pudeceng).

4. Temmangowa (not greedy). It is also one implementation of the values of honesty, that does not take not qualified (temmangoangenngi tenia alona), which indicates that the adoption in Bugis tradition does not make the adopted child shall be the sole heir of much less is not the beneficiary. If the adopted child take the treasures with the adoptive parents and the heritage status or through grants and will exceed the provisions of religion then it is deemed contrary to the cultural values of temmangowa.

5. Value of asitinajang (propriety). Decency, decorum, decency in Bugis called asitinajang. The word is derived from the mean tinajawhich refers to suitable, appropriate, proper or improper. Lontarak said: "Occupy your position, occupied place." ${ }^{3}$ Ade 'Wari' (traditional distinction) in Bugis culture in principle to arrange everything in order to be in place, including mappasitinaja deeds. Destructive order is injustice. This is in accordance with the advice: "Alai cedde'e

32 Note intent Q.s. al-Maidah [5]: 32.

33 A. Rahman Rahim, Core Values, p. 129. 
risesena engkai mappideceng, sampeangngi maegai risesena engkai makkasolang". ${ }^{34}$ Meaning: "Take that bit if that bit of it for good, and deny that much if it brings a lot of destruction/damage". Thus, the adopted child is not entitled and did not deserve as a legacy of treasures treasure adoptive parents, but are entitled to a property through a will, whereas the will is a maximum $1 / 3$ of the treasure. $1 / 3$ is considered little then remains that are worth by Islam and minimize the potential for conflict.

6. Paccing (holy). This can be seen through the poem of the Bugis "Duwai kuala Sappo; unganna panasae, belona kanukue "It meanstwo (things) can be a fence (protective and honor), the jackfruit flowers and decoration nails". ${ }^{35}$ In the context of adoption, paccing philosophy is in line with the Maqasid al-Shariah (the main purpose of the Shari'a) are the breeding. Prohibition adoption change the status of biological children adopted children be aimed at keeping the sanctity of the origin of the offspring.

${ }^{34}$ A. Rahman Rahim, Core Values, p. 130, Machmud quoted from A. Hasan, 76, item 108.

${ }^{35}$ In the tradition of the Bugis two highly respected norms apart from religious norms, namely siri and passe'. Siri "is" self-esteem", which is a principal ingredient in themselves for the Bugis. For the Bugis, siri 'is their soul, their pride and their dignity. Therefore, in order to uphold and defend 'siri' is considered contaminated or polluted by other people, the Bugis people would be willing to sacrifice anything, including the most precious souls for the sake siri 'in their lives. Human Bugis-Makassar: An Historical Overview of the Patterns of Behavior and Worldview Bugis-Makassar (Jakarta: IntiDayu, 1985), p. 37. While passe is a sense of solidarity among the Bugis, which is a value at which to feel the suffering of others with compassion (empathy) deep for others. Human Bugis, trans. Abdul Rahman Abud et al., The Bugis Christian Pelras, (Jakarta: Reason cooperate Forum Jakarta-Paris, EFEO, 2005), p. 254. Compare with Mursalim, "Commentary Language Bugis/Tafsir al-Qur'an al-Karim work of the Indonesian Ulema Council (MUI ) South Sulawesi; Study of the Thought-Thinking", Dissertation, (Jakarta: UIN Syarif Hidayatullah, 2008), p. 231-232. See also about Bugis, Idrus, Nurul Ilmi. "Behind the Notion of Siala: Marriage, Adat and Islam among the Bugis in South Sulawesi." Intersections: Gender, History and Culture in the Asian Context 10 (2004). Charles Campbell Macknight, "A Bugis Manuscript about Praus.” Archipel 18, no. 1 (1979): p. 271282. Susan Bolyard Millar, "On Interpreting Gender in Bugis Society." American Ethnologist 10, no. 3 (1983): p. 477-493. Gregory L Acciaioli, "Bugis Entrepreneurialism and Resource Use: Structure and Practice." Antropologi Indonesia (2014). Munsi Lampe, "Bugis-Makassar Seamanship and Reproduction of Maritime Cultural Values in Indonesia." Humaniora 24, no. 2 (2012): p. 121-132. Richard Feinberg, "Bugis Navigation." American Anthropologist 103, no. 3 (2001): p. 853-854. 
7. Lempu'. Related in point 6 above, the word 'Panasa' on 'ungannapanasae' which is synonymous with the word "lempu". ${ }^{36}$ When pressurized the glottal stop (') on the last syllable into lempu', the word changes its meaning to 'honesty'. Similarly, the word "belonakanukue", used to decorate the nails (beloKanuku) called Pacci. Pacci said, if given the additional sound of "ng" at the end of Pacci be paccing word, the word change its meaning becomes stained, clean, and pure. Thus, "Duwai kuala Sappo; unganna panasae, belona kanukue "can mean" the two were always used as a fence, that is the sanctity and honesty". ${ }^{37}$ Conceal or falsify documents or description of the origins and nasab of someone is an act or practice that is contrary to the principles and culture of lempu '(honest) including practices in changing the name of the biological parents to the adoptive parents.

When Tociung, scholars of Luwu, consulted by the future king (datu) Soppeng, La Manussa 'Toakkareng, Tociung stated, there are four acts honestly, namely:

"Eppa 'gau'na lempu'e: risalaie naddampeng, riparennuangie temmacekko bettuanna risanresi teppabbelleang, temmangoangenngi tenia alona, tennaseng Deceng Rekko nassamarini pudeceng". ${ }^{38}$

\section{This means:}

"There are four core honest actions: (1). forgive those who do wrong to him, (2). then believed not cheating, then leaned meaning does not lie, (3) not say thing that is not right, and (4) do not look if only for her goodness, her kindness that can be enjoyed together.

${ }^{36}$ Mattulada, "Latoa; A Painting of the Political Anthropology Bugis", Dissertation (Jakarta: University of Indonesia, 1975), p. 13 See also Mursalim, Bugis Language Interpretation, p. 232

${ }^{37}$ One of the unique language of Lontarak is in one word may have very different meanings to other meanings as well as readings, because in his writing does not have specific signs, such shadda (letter doble) and maddah (length). Examples of words bk $(\mathrm{ba}+\mathrm{ka})$ can be read with a variety of sounds, each of which has its own meaning. The words can be read bk (baka) which means that the basket; but it can also be read bk (baka) which means breadfruit, and can also be read bk (Bakka ') which means that the fruit is not ripe (still half-baked).

${ }^{38}$ A. Rahman Rahim, Core Values Culture Bugis, p. 119-120. He quotes from Lontarak belongs to H. Andi Mappasala. Phrase “... tennaseng Deceng Rekko nassamarini pudeceng” it seems ambiguous. In accordance with the meaning "do not look if only for her goodness, her kindness had said that can be enjoyed together" should sound less so "... tennaseng Deceng rekko-Deceng rialemi, iyapa nariasenng Deceng rekko-nassamarini pudeceng. 
Correspondingly, Kajaolaliddong, scholars of Bone, explaining honesty when asked by King Bone on scientific subjects. Any witness or evidence of honesty? "The call ya Ampone" What are we called Kajao huh? "As called for are:

"Aja 'muala taneng-taneng tania-tanengmu taneng. wrote 'muala warangmachete-parangmu tania Warang nataniato mana'mu, aja'to mupassu tedong tedongmu Natania, enrengnge annyarang tania anynyarangmu, aja'to muala aju ripasanre' natengnia iko pasanre'i, aja'to muala aju riwetta guardian netengnia iko mpetta waliwi. ${ }^{39}$

This means:

"Do not take a plant that is not yours, do not take things that are not things, nor inheritance; do not remove the buffalo (of the cage) if they are not yours, also a horse that is not your horse, do not take the timber resting, not you that lean, not too wooden is made tip base, which is not yours."

This message indicates the commitment of honesty, that does not take away the rights of others. Not taking that is not right, including adopted children and adoptive parents can not be and are not entitled to inherit each other. They are not entitled to material possessions, except by way of a will and grants in accordance with Islam.

\section{Conclusion}

The forms of adoption (tabanniy) can be divided into two forms. First, adoption (tabanniy) which is forbidden as tabanniy practiced by jahilliyah and secular civil law makes an adopted child as biological children with all the rights as biological children, disconnect nasab with parental origin, attributing his name to his stepfather. Secondly, adoption (tabanniy) are allowed and even encouraged, the removal of children who are driven by motivations of worship to Allah. To bear the daily living, education expenses, maintenance, and others without having to disconnect nasab with biological parents, not have nasab of his adoptive parents.

${ }^{39}$ A. Rahman Rahim, Core Values Culture Bugis, p. 120. 
The human propensity to practice adoption among others is to assist each other between the inheritance inherit both the adoptive parents to adopted children and vice versa. It aims to maintain the property and rights of other heirs. Adopted children and adoptive parents are entitled to a property with the grant status and testament. In addition, the adoption of children should also not be contrary to the intention of the Sharia, which is the breeding. Adoption with no legal implications, does not change the status of mahram. A female foster child can be married by her stepfather, as well as the foster son can marry his adoptive mother when she was officially divorced or divorced.

Under these conditions, an explanation of the adoption laws in Islam should be categorized into a theme in the study or lecture. Adoption practices that took place in the community still has a lot of forms and motifs, as in the time of ignorance, when it was banned by the primary text of Islam. The approach taken should see Bugis community in three positions; (1) as Indonesian citizens there should be laws or regulations on the adoption of a child; (2) as Muslims must understand Islamic law on adoption; (3) as the Bugis, they have the values of local wisdom that should be highly appreciate. Thirdly it can not contradict to each other, even to be aligned in order to be effective.

\section{Bibliography}

Acciaioli, Gregory L. "Bugis Entrepreneurialism and Resource Use: Structure and Practice." Antropologi Indonesia (2014).

Bargach, Jamila. Orphans of Islam: Family, Abandonment, and Secret Adoption in Morocco. Vol. 2. (Rowman \& Littlefield Publishers, 2002).

Bzn, B Ter Hear. Beginselen en Stelsel van het Adat Rech, trans. Soebakti Poesponoto, Jakarta: Paramadina, 1976.

El Saadawi, Nawal. "Woman and Islam." In Women's Studies International Forum, vol. 5, no. 2, Pergamon, 1982.

Fakhr El-Islam, M. "Arab Culture and Mental Health Care.” Transcultural psychiatry 45, no. 4 (2008): 671-682. 
Faradz, Haedah. "Pengangkatan Anak Menurut Hukum Islam.” Jurnal Dinamika Hukum 9, no. 2 (2009): 191-198.

Feinberg, Richard. "Bugis Navigation.” American Anthropologist 103, no. 3 (2001): 853-854.

Gil'adi, Avner. Children of Islam: Concepts of Childhood in Medieval Muslim Society. Springer, 1992.

Göle, Nilüfer. "The Voluntary Adoption of Islamic Stigma Symbols." Social Research: An International Quarterly 70, no. 3 (2003): 809-828.

Hariadi, Tresna. "Hak Anak Angkat dari Orang Tua Angkat dalam Hukum Islam (Studi Pada Pengadilan Agama Medan).” Master's thesis, 2004.

Idrus, Nurul Ilmi. "Behind the notion of siala: Marriage, adat and Islam among the Bugis in South Sulawesi." Intersections: Gender, History and Culture in the Asian Context 10, (2004).

Ijzendoorn, Van, Marinus H., and Femmie Juffer. “The Emanuel Miller Memorial Lecture 2006: Adoption As Intervention. Meta-Analytic Evidence for Massive Catch-up and Plasticity in Physical, SocioEmotional, and Cognitive Development." Journal of Child Psychology and Psychiatry 47, no. 12, (2006): 1228-1245.

Ishaque, Shabnam. "Islamic Principles on Adoption: Examining the Impact of Illegitimacy and Inheritance Related Concerns in Context of A Child's Right to An identity." International Journal of Law, Policy and the Family 22, no. 3 (2008): 393-420.

Isnaini, Enik. "Hukum Hibah Wasiat Terhadap Anak Angkat Menurut Hukum Perdata.” Jurnal Ilmu Sosial dan Humaniora. Fakultas Hukum Universitas Islam Lamongan.

Khusdjono. "Pengangkatan Anak dan Akibat Hukumnya Terhadap Harta Benda Perkawinan Orang Tua Angkat (Studi Pada Masyarakat Tionghoa di Kecamatan Senapelan Kota Pekanbaru).” Premise Law Journal 2, (2015).

Lampe, Munsi. "Bugis-Makassar Seamanship and Reproduction of Maritime Cultural Values in Indonesia." Humaniora 24, no. 2 (2012): 121-132. 
Macknight, Charles Campbell. “A Bugis Manuscript about Praus.” Archipel 18, no. 1 (1979): 271-282.

Mahmud Syaltut. Al-Fatawa. Mishr: Dar al-Qalam, t.t.

Mattulada. "Latoa; A Painting of the Political Anthropology Bugis", Dissertation, Jakarta: University of Indonesia, 1975.

Millar, Susan Bolyard. "On Interpreting Gender in Bugis Society." American Ethnologist 10, no. 3 (1983): 477-493.

Mursalim, "Commentary Language Bugis / Tafsir al-Qur'an al-Karim work of the Indonesian Ulema Council (MUI ) South Sulawesi; Study of the Thought-Thinking”, Dissertation, Jakarta: UIN Syarif Hidayatullah, 2008.

MUI South Sulawesi. Tafesere Akorang Mabbasa Ogi, Volume 1. Ujung Pandang: MUI Sulawesi, 1988.

Nasution, Khoiruddin. "Perlindungan Terhadap Anak dalam Hukum Keluarga Islam di Indonesia”, Al-Adalah 13, no. 1 (June 2015): 1-10.

Nurlaelawati, Euis. "Menuju Kesetaraan dalam Aturan Kewarisan Islam Indonesia: Kedudukan Anak Perempuan versus Saudara Kandung.” Jurnal Indo-Islamika 2, no. 1 (2012): 75-90.

Opeloye, Muibi O. "Child Rights Act 2003 in Nigeria: What Implications for the Application of Child's Rights in Islam?.” Proceedings Of ICWC, Subang Jaya, Malaysia, 2016.

Puspita, Rany. "Adopsi Anak (Studi Deskriptif Tentang Latar Belakang dan Nilai Anak Bagi Pasangan Suami Istri Yang Mengadopsi Anak).” Phd Diss., Universitas Airlangga, 2006.

Prabowo, Muhammad Aras, and Hadri Mulya. "Construction of Ethic Code of Public Accountant in Perspective of Value of Bugis Culture." International Journal of Applied Business and International Management 3, no. 2, (2018): 5-18.

Qurthubi, Abu Abdullah Muhammad al-. Jami' li Ahkam al-Qur'an, 14 Juz, Mecca: Muassasah al-Risalah, t.t.

Rahman, Nurhayati. Voices in the Locality. Makassar: Lagaligo Press, 2012. Rahim, A. Rahman. Core Values Culture Bugis. Yogyakarta: Waves, 2011. 
Ramdhani, Ria. "Pengaturan Wasiat Wajibah Terhadap Anak Angkat Menurut Hukum Islam.” Lex Et Societatis 3, no. 1 (2015).

Rajabi-Ardeshiri, Massoud. "The Rights of the Child in the Islamic

Context: The Challenges of the ILocal and the Global." Int'l J. Child. Rts. 17 (2009): 475.

Ryan, Richard M., and Edward L. Deci. "Intrinsic and Extrinsic Motivations: Classic Definitions and New Directions." Contemporary Educational Psychology 25, no.1, (2000): 54-67.

Sangian, Filemon. "Hak Atas Warisan Seorang Anak yang Diadopsi Terhadap Orang Tua Walinya Menurut KUH Perdata." Lex Et Societatis 5, No. 2 (2017).

Sonbol, Amira al-Azhary. "Adoption in Islamic Society: A Historical Survey." Children in the Muslim Middle East (1995): 45-67.

Syafi'i, Ahmad. "Adopsi dalam Perspektif Hukum Perdata, Hukum Adat dan Hukum Islam.” HUNAFA: Jurnal Studia Islamika 4.1 (2007): 49-62. Talbani, Aziz. "Pedagogy, Power, and Discourse: Transformation of Islamic Education." Comparative Education Review 40, no. 1, (1996): 66-82.

Usman, Munadi. "Adopted Children and The Right of Civilization According to the Qur'an." QURANICA-International Journal of Quranic Research 10, no.1, (2018): 27-40.

Winarno, Jatmiko. "Akibat Hukum Pengangkatan Anak." Jurnal Humaniora 1, no. 2 (2013): 1-14.

Wekke, Ismail Suardi. "Islam dan Adat: Tinjauan Akulturasi Budaya dan Agama dalam Masyarakat Bugis." Analisis: Jurnal Studi Keislaman 13, no.1, (2017): 27-56.

. "Islam dan Adat dalam Pernikahan Masyarakat Bugis di Papua Barat." THAQAFIYYAT: Jurnal Bahasa, Peradaban dan Informasi Islam 13, no. 2. (2014).

Yunus, Rasid. "Transformasi Nilai-nilai Budaya Lokal Sebagai Upaya Pembangunan Karakter Bangsa.” Jurnal Penelitian Pendidikan 13, no. 1, (2016).

Zuhdi, Masjfuk, Masail Fiqhiyah. Jakarta: CV. Masagung, 1994. 
Zilal, S., and M. Y. Farahwahida. "Penyusuan Anak Angkat: Satu Analisis." Prosiding Persidangan Antarabangsa Kekeluargaan dari Perspektif Global. Johor Bahru: KPIJ PRESS (2014): 124-144.

\section{Interview}

Syamsul Bahri Andi Andi Galigo, Interview, Malaysia August 28, 2008. 